\title{
Comparison of the effects of two bongo net mesh sizes on the estimation of abundance and size of Engraulidae eggs
}

\author{
Jana Menegassi del Favero ${ }^{1, *}$, Mario Katsuragawa ${ }^{1}$, Maria de Lourdes Zani-Teixeira ${ }^{1}$, \\ Jefferson T. Turner ${ }^{2}$
}

\author{
${ }^{1}$ Instituto Oceanográfico da Universidade de São Paulo \\ (Praça do Oceanográfico, 191, 05508-120 - Butantã - São Paulo - SP, Brasil) \\ ${ }^{2}$ University of Massachussets \\ (Dartmouth - 285 Old Westport Road - Dartmouth, MA 02747-2300)
}

*Corresponding author: delfaverojana@gmail.com

\begin{abstract}
Studies of ichthyoplankton retention by nets of different mesh sizes are important because they help in choosing a sampler when planning collection and the establishment of correction factors. These factors make it possible to compare studies performed with nets of different mesh sizes. In most studies of mesh retention of fish eggs, the taxonomic identification is done at the family level, resulting in the loss of detailed information. We separated Engraulidae eggs, obtained with $0.333 \mathrm{~mm}$ and $0.505 \mathrm{~mm}$ mesh bongo nets at 172 oceanographic stations in the southeastern Brazilian Bight, into four groups based on their morphometric characteristics. The difference in the abundance of eggs caught by the two nets was not significant for those groups with highest volume, types A and B, but in type C (Engraulis anchoita), the most eccentric, and in type $\mathrm{D}$, of the smallest volume, the difference was significant. However, no significant difference was observed in the egg size sampled with each net for E. anchoita and type D, which exhibited higher abundance in the $0.333 \mathrm{~mm}$ mesh net and minor axis varying from $0.45-0.71$ $\mathrm{mm}$, smaller than the $0.505 \mathrm{~mm}$ mesh aperture and the mesh diagonal.
\end{abstract}

Descriptors: Ichthyoplankton, Engraulis anchoita, Mesh size, Capture Efficiency, SE Brazil.

\section{Resumo}

Estudos sobre a retenção do ictioplâncton por redes com diferentes tamanhos de malhas são importantes, pois ajudam na escolha do amostrador durante o planejamento da coleta e possibilitam o estabelecimento de fatores de correção. Tais fatores permitem a realização de comparações entre trabalhos realizados com diferentes malhagens. $\mathrm{Na}$ maioria dos estudos focando a retenção de ovos de peixes por diferentes tamanhos de malhas, a identificação taxonômica é feita até o nível de família, resultando na perda de informações mais detalhadas. Os ovos analisados foram obtidos em 172 estações oceanográficas realizadas na Plataforma Continental Sudeste do Brasil, com rede bongô de malhas 0,333 e $0,505 \mathrm{~mm}$. Os ovos de Engraulidae foram separados em quatro tipos de acordo com características morfométricas tipos A, B, C (Engraulis anchoita) e D, ovos de menor volume. Apenas os ovos de E. anchoita, de maior excentricidade, e do tipo $\mathrm{D}$, de menor volume, foram significativamente mais abundantes na rede de 0,333 $\mathrm{mm}$, embora suas dimensões não tenham diferido entre as capturas realizadas com as duas malhagens e o tamanho do eixo menor desses dois tipos não tenha excedido $0,71 \mathrm{~mm}$, valor semelhante à diagonal $\mathrm{da}$ malha de $0,505 \mathrm{~mm}$.

Descritores: Ictioplâncton, Engraulis anchoita, Tamanho de Malhagem, Eficiência de Captura, SE Brasil. 


\section{INTRODUCTION}

A historical analysis of the development of quantitative zooplankton collecting systems, from the hensen net to the four-dimensional biological oceanography, has been presented by WIEBE and BENFIELD (2003). Even with the sophisticated sampling systems available to quantify the abundance of planktonic organisms, for example those using acoustic and optical technologies, less sophisticated net-based sampling devices remain in widespread use. This reliance on simple nets is due to the relatively low expense of the sampling gear, the ease of deployment, and to the desire to maintain a standard protocol over a long time series (JOHNSON; FOGARTY, 2013).

Much attention has been focused recently on multi-decadal time-series of marine organisms (e.g. BRODEUR et al., 1996; MULLIN, 1998; NAGASAWA, 2001; STRATOUDAKIS et al., 2003; AUTH et al., 2011; TURNER et al., 2011). Few long time-series data are available, and many that exist are complicated by the changes in methodology that have been made over the years. The long-term time-series contain much information which would be valuable were the results obtained by the different methods comparable or if calibration factors could be determined for the different methods (REBSTOCK, 2002). For example, the California Cooperative Oceanic Fisheries Investigations (CalCOFI) program has sampled zooplankton off the west coast of North America since 1949, but in 1978 the $1 \mathrm{~m}$ diameter ring net was replaced by a bongo net, with two $0.71 \mathrm{~m}$ diameter nets on a single frame, so REBSTOCK (2002) determined whether (debated whether/attempted to determine how far the estimates of abundance of calanoid copepods collected with the ring and bongo net were comparable. For the Brazilian coast, the Biological Collection "Prof. E. F. Nonato" (ColBIO) of the Oceanographic Institute, University of São Paulo, Brazil, contains zooplankton samples collected in the southeastern Brazilian Bight since the 1960s, but the mesh sizes used have not always been the same, and this calls for studies on the effect of the mesh-size when sampling different taxonomic groups, to allow multi-decadal and multi-annual comparisons.

The ideal sampler for zooplankton is one whose selective characteristics are appropriate, qualitatively and quantitatively, to the problem under study (BARKLEY, 1972). Sampling programs and devices must provide accurate measurements of changes in abundance and levels of precision that permit the detection of variations in key parameters for a proper understanding of the processes that influence population dynamics. It is important that the survey design should provide adequate spatial and temporal resolution and that the correct sampling gear and mesh size be chosen to minimize sampling bias for the organisms under study (PEPIN; SHEARS, 1997).

A number of studies have documented comparisons of different kinds of sampling gear. PEPIN and SHEARS (1997) compared the variability and capture efficiency of bongo nets and Tucker trawls in the collection of ichthyoplankton and other macrozooplankton, concluding that both samplers are efficient at catching a wide range of sizes of larval fish, with bongo nets being more effective for smaller larvae and the Tucker trawl for larger ones. The evaluation of catchability of fish eggs and larval fish with the $0.61 \mathrm{~m}$ bongo and the $1 \mathrm{~m}^{2}$ Multiple Opening and Closing Net Environmental Sensing System (MOCNESS) was conducted by JOHNSON and FOGARTY (2013), showing that overall catches of fish larvae and eggs were significantly higher for the MOCNESS, which filtered 3.5 times more seawater than the bongo; but bongo nets were more efficient in collecting some larval taxa in the larger size classes. Those authors reinforced the idea that the catchability of sampling gear of larval taxa is species-specific and advanced-stage-specific. In many cases, such as when sampling effectively all sizes of leptocephali, two types of nets/trawls will likely be needed (MILLER et al., 2013).

An inter-comparison and evaluation of methods for sampling and determination of zooplankton distribution and biomass was recently conducted and included 14 zooplankton sampling instruments: four multiple opening and closing net systems (1- and 10- $\mathrm{m}^{2}$ MOCNESS, 1- $\mathrm{m}^{2}$ BIONESS, $0.25-\mathrm{m}^{2}$ MultiNet), three high-speed samplers (LHPR, Gulf-V, CPR), one optical plankton counter (OPC), 4 vertically or obliquely hauled nets (WP-2.20- and 60-cm Bongo, 1-m Ring net (CalCOFI)), and two micronekton trawls (MIK ring net, young-fish trawl) (SKJOLDAL et al., 2013). The results of this study showed that different vertical, oblique, and multiple opening/closing net systems produced similar estimates of zooplankton when operated with comparable mesh sized nets, the mesh size of the net exercising the greatest influence on the biomass and species composition of the zooplankton community.

Focusing on ichthyoplankton collections, comparisons of the efficiency of different mesh sizes has been documented by various authors (e.g. HOUDE; LOVDAL, 1984; JOHNSON; MORSE, 1994; SOMARAKIS et al., 
1998). However, only a few of these studies included fish eggs in the comparison, analyzing rather the total of eggs sampled (e.g. CHUTE; TURNER, 2001; HERNANDEZ et al, 2011). The studies that compare the effects of mesh size on sampling a specific egg family is usually done with Engraulidae, because they are easy to identify due to their ellipsoid shape, segmented yolk and, usually, absence of oil droplets (CIECHOMSKI, 1965; PHONLOR, 1985). SOMERTON and KOBAYASHI (1989) compared the catch of Hawaii anchovy eggs in two plankton nets, one with $0.183 \mathrm{~mm}$ mesh size and the other with $0.335 \mathrm{~mm}$; MATSUURA and NAKATANI (1980) and SANCHEZ and CIECHONSKI (1984) compared the catch of Engraulis anchoita Hubbs \& Marini, 1935 eggs using a bongo net fitted with 0.333 and $0.505 \mathrm{~mm}$ mesh size nets, producing contradictory results.

Engraulids are small pelagic fish ecologically important as secondary consumers near the bottom of the food chain and essential prey for other fish, marine mammals and seabirds, at the top of the food chain, thus linking the bottom of the chain with the top (CASTELLO, 2007). Some Engraulidae species are also important fishery resources (FAO, 2012). Along the southern Brazilian coast it is estimated that up to 135,000 tonnes of Engraulis anchoita could be sustainably exploited (MADUREIRA et al., 2009), however its exploitation has only recently started in this area (CARVALHO; CASTELLO, 2013).

In view of the environmental and fisheries significance of the Engraulidae family, the importance of long time-series studies, the lack of information on the catchability of different Engraulidae eggs and the contradictory results of the two studies on the west Southern Atlantic coast, the main objective of the present study is to compare the effects of the bongo net mesh size on the measurement of the abundance and size of four types of Engraulidae eggs in the southeastern Brazilian Bight. The null hypotheses are that the frequency of occurrence, the abundance and the size of the Engraulidae eggs types are the same, regardless of whether the 0.333 $\mathrm{mm}$ or the $0.505 \mathrm{~mm}$ mesh size net is used.

\section{MATERIAL AND METHODS}

\section{DATA COLLECTION AND PREPARATION}

Ichthyoplankton samples were collected at 140 stations from November $29^{\text {th }}$ to December $18^{\text {th }}, 1975$ and at 32 stations from March $8^{\text {th }}$ to $15^{\text {th }}, 1982$. All the stations were located in the southeastern Brazilian Bight $\left(23^{\circ} \mathrm{S}-29^{\circ} \mathrm{S}\right)$ as shown in Figure 1. The sampling procedure described by Smith and Richardson (1977) was followed, using a bongo net with a $0.61 \mathrm{~m}$ diameter mouth opening, equipped with paired cylindrical-conical $0.333 \mathrm{~mm}$ and $0.505 \mathrm{~mm}$ mesh size nets. To measure filtered water volume a flowmeter was attached at the center of the mouth of each net. A depressor was applied to the net which was towed obliquely from the surface to a maximum depth not exceeding 200 $\mathrm{m}$, and then back to the surface, maintaining a wire angle near $45^{\circ}$. At stations shallower than $60 \mathrm{~m}$ the bongo net was lowered twice close to the bottom to increase the volume of water filtered. Towing speed was of about 1.5 - 2 knots. All samples were preserved in $4 \%$ buffered formalin in seawater and stored in the Biological Collection "Prof. E. F. Nonato" (ColBIO) of the Oceanographic Institute, University of São Paulo, Brazil.

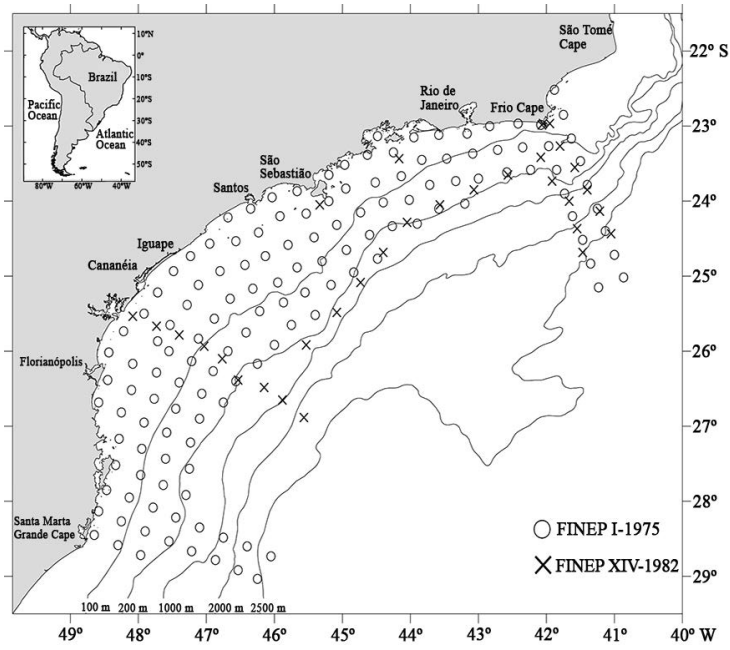

Figure 1. Location of the sample stations in the southern Brazilian Bight during 1975 and 1982.

Engraulidae eggs were sorted and identified by their morphometric characteristics in four groups, types A, B, $\mathrm{C}$ (Engraulis anchoita) and D, as described by FAVERO et al. (2014). Major and minor egg axes were measured automatically through photographs using the program ImageJ. All Engraulidae eggs of each group were measured, except when the number of individuals for a given group exceeded 100. In these instances, 100 eggs were randomly selected for measurement.

\section{DATA ANALYSES}

Frequency of occurrence (FO) for each egg type in each mesh size net was calculated by $\mathrm{FO}=(\mathrm{pi} / \mathrm{p}) * 100$, where pi was the number of stations where the egg 
type "i" was present, and $p$ the total number of stations (GUILLE, 1970).

For data descriptions and analyses the number of Engraulidae eggs was standardized according to the volume of seawater filtered (eggs $/ \mathrm{m}^{3}$ ).

As our abundance data were not normally distributed and the samples are dependent, to verify the influence of the mesh size on volume of seawater filtered, volume of plankton and abundance of fish eggs, the non-parametric Wilcoxon paired-sample test (ZAR, 1999) was performed. Although a few studies have compared the effects of different mesh-sizes on the plankton catch using consecutive tows (SOMERTON; KOBAYASHI, 1989; CHUTE; TURNER, 2001; TSENG et al., 2011; MAKABE et al., 2012), factors such as tow depth, tow time and net speed are difficult to control when separate tows are made and compared. As the bongo net was fitted with two different mesh size nets, all the factors cited above were the same at each station, enabling a pairwise correlation of the data from the two nets, as was done by MATSUURA and NAKATANI (1980), and SANCHEZ and CIECHONSKI (1984). In this case, a paired-sample test will be more powerful than the two-sample test (ZAR, 1999). This analysis was done only at the positive stations, meaning that only at the stations where Engraulidae eggs were collected in at least one mesh size net.

The difference in the egg axes size per mesh was tested by the two sample Student's $t$-test, with confidence level of $99 \%(p<0.01)$.

All the analyses described were made using R software (R Core Team, 2012).

\section{RESULTS}

A total of 306,711 fish eggs were collected, 66,331 $(21.63 \%)$ of them being of the Engraulidae family. Engraulis anchoita represented $92.89 \%(n=61,615)$ of all Engraulidae egg samples, followed by type D, with $3.26 \%$ $(\mathrm{n}=2,160)$, type A with $2.95 \%(\mathrm{n}=1,960)$ and type B with $0.90 \%(\mathrm{n}=596)$.

Of the 172 oceanographic stations sampled, only at two were there no fish eggs. Engraulidae eggs were found at $38.95 \%$ of the stations. Engraulis anchoita was the Engraulidae with the highest FO, of $31.40 \%$. Again, $E$. anchoita was followed by type D, with $16.28 \%$, type A with $8.14 \%$ and type B with $7.56 \%$ FO.

As Engraulidae eggs were present at only five stations during 1982, all the statistical analyses were undertaken for both years together.
For type B eggs, FO was the same for both nets; however, at six stations this type occurred only in the $0.505 \mathrm{~mm}$ mesh size and at the other six stations, only in the 0.333 $\mathrm{mm}$. For type A, FO was higher in the $0.505 \mathrm{~mm}$ mesh net, but at two stations type A eggs occurred only in the 0.333 $\mathrm{mm}$ mesh net. For E. anchoita and type D eggs, FO was higher in the $0.333 \mathrm{~mm}$ mesh net, though they were present in the $0.505 \mathrm{~mm}$ mesh net but absent in the $0.333 \mathrm{~mm}$ mesh net at 10 and 5 stations, respectively (Table 1).

Table 1. Frequency of occurrence (FO) in the $0.333 \mathrm{~mm}$ and the $0.505 \mathrm{~mm}$ mesh net; number of stations $(\mathrm{N})$ where the egg types occurred in just one of the nets.

\begin{tabular}{lcccc}
\hline & \multicolumn{2}{c}{ FO (\%) } & \multicolumn{2}{c}{ N } \\
\hline & $0.333 \mathrm{~mm}$ & $0.505 \mathrm{~mm}$ & $0.333 \mathrm{~mm}$ & $0.505 \mathrm{~mm}$ \\
Total eggs & 98.84 & 98.84 & & \\
Engraulidae eggs & 27.91 & 27.91 & 19 & 19 \\
Type A & 2.91 & 6.98 & 2 & 9 \\
Type B & 4.07 & 4.07 & 6 & 6 \\
E. anchoita & 25.00 & 18.60 & 22 & 10 \\
Type D & 13.37 & 8.14 & 14 & 5 \\
\hline
\end{tabular}

Even with the volume of water filtered being greater in the $0.505 \mathrm{~mm}$ mesh net, the median volume of plankton and the median abundance of total fish eggs and of Engraulidae eggs were higher in the $0.333 \mathrm{~mm}$ mesh size net. Among the Engraulidae, the median abundances of eggs of types A and B estimated for the two mesh sizes were not significantly different, but the median abundance of E. anchoita and type D was higher in the $0.333 \mathrm{~mm}$ mesh net (Table 2).

The egg abundance differences between the 0.333 and $0.505 \mathrm{~mm}$ mesh nets varied at each station for each egg type, showing no constant pattern (Figure 2). Type A and type B showed low values of abundance differences between the 0.333 and $0.505 \mathrm{~mm}$ mesh nets. For E. anchoita, there was only one station where the egg abundance sampled with the $0.505 \mathrm{~mm}$ mesh net was much higher than the egg abundance sampled with the $0.333 \mathrm{~mm}$ mesh, with an abundance difference of $114 \mathrm{eggs} / \mathrm{m}^{3}$; at the other stations, more E. anchoita eggs were sampled with the 0.333 $\mathrm{mm}$ mesh net, with difference values varying from almost zero to $41.08 \mathrm{eggs} / \mathrm{m}^{3}$. For type D eggs, at most stations the $0.333 \mathrm{~mm}$ mesh net sampled more eggs than the 0.505 $\mathrm{mm}$ mesh net, and only in a few cases was the $0.505 \mathrm{~mm}$ mesh net more efficient than the 0.333 one, but with low difference values, less than $0.08 \mathrm{eggs} / \mathrm{m}^{3}$.

The stations that sampled more E. anchoita and type D eggs with the $0.505 \mathrm{~mm}$ net were not associated 
Table 2. Amplitude and median values of sea water filtered volume $\left(\mathrm{m}^{3}\right)$, plankton volume $\left(\mathrm{ml} / \mathrm{m}^{3}\right)$ and egg abundance $($ eggs/ $\mathrm{m}^{3}$ ) collected with $0.333 \mathrm{~mm}$ and $0.505 \mathrm{~mm}$ mesh nets in the southern Brazilian Bight during 1975 and 1982. $P$-values $(P)$ of Wilcoxon paired-sample test and number of positive stations $(\mathrm{N})$.

\begin{tabular}{|c|c|c|c|c|c|c|c|}
\hline & & \multicolumn{2}{|c|}{ Amplitude } & \multicolumn{2}{|c|}{ Median Value } & \multirow[t]{2}{*}{$\boldsymbol{P}$} & \multirow[t]{2}{*}{$\mathbf{N}$} \\
\hline & & $0.333 \mathrm{~mm}$ & $0.505 \mathrm{~mm}$ & $0.333 \mathrm{~mm}$ & $0.505 \mathrm{~mm}$ & & \\
\hline Filtered volume $\left(\mathrm{m}^{3}\right)$ & & $79.5-690.7$ & $85.9-690.7$ & 235.1 & 268.5 & $<0.01$ & 172 \\
\hline \multirow[t]{3}{*}{ Plankton volume $\left(\mathrm{ml} / \mathrm{m}^{3}\right)$} & & $0.02-2.67$ & $0.01-2.14$ & 0.27 & 0.18 & $<0.01$ & 172 \\
\hline & Total eggs & $0-330.7$ & $0-128.6$ & 0.97 & 0.67 & $<0.01$ & 170 \\
\hline & Total Engraulidae & $0-54.9$ & $0-117.2$ & 0.09 & 0.01 & $<0.01$ & 67 \\
\hline \multirow[t]{4}{*}{ Abundance* (eggs/m³) } & Type A & $0-2.92$ & $0-8.21$ & 0 & 0.04 & 0.15 & 14 \\
\hline & Type B & $0-0.76$ & $0-2.95$ & 0 & 0.01 & 1 & 13 \\
\hline & Engraulis anchoita & $0-53.75$ & $0-114.5$ & 0.24 & 0 & $<0.01$ & 54 \\
\hline & Type D & $0-7.11$ & $0-2.70$ & 0.03 & 0 & $<0.01$ & 28 \\
\hline
\end{tabular}

* Positive stations.
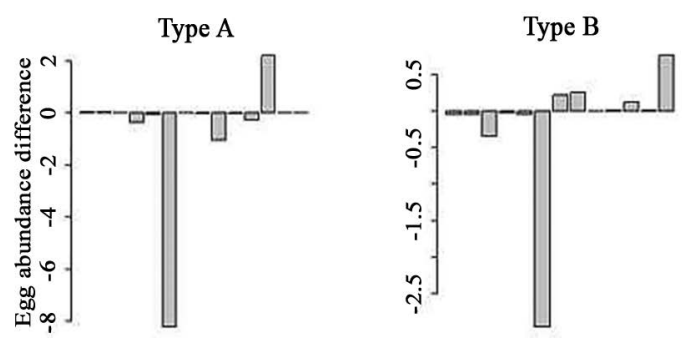

Engraulis anchoita
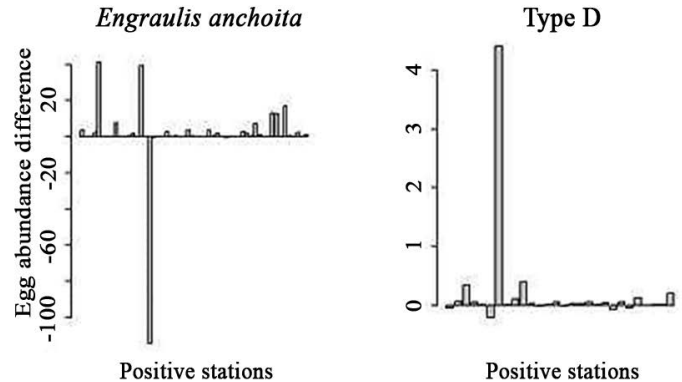

Figure 2. Differences (eggs $/ \mathrm{m}^{3}$ ) between the four types of Engraulidae egg abundances sampled by $0.333 \mathrm{~mm}$ and $0.505 \mathrm{~mm}$ mesh net in the southern Brazilian Bight, during 1975 and 1982. Positive values mean that the abundance of eggs sampled by $0.333 \mathrm{~mm}$ mesh size was higher than that of the $500 \mathrm{~mm}$, and negative values the opposite.

with the stations that presented higher abundance of plankton (Figure 3).

Mean value of the major axis was significantly different between mesh size nets for types A, B and $E$. anchoita; no significant difference being observed for type D. Types A and B eggs also had different mean values of the minor axis for the two nets, however no significant difference was observed for E. anchoita and type D eggs (Table 3). The low size range of the egg axes in the four egg types identified may be seen in Table 3 .
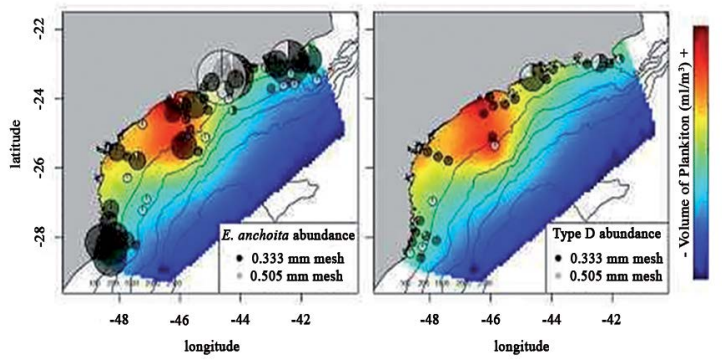

Figure 3. Bubble plot of the egg abundance logarithmized (represented by circles) of E. anchoita (left) and type D (right), and the proportion of eggs sampled with the $0.333 \mathrm{~mm}$ and the $0.505 \mathrm{~mm}$ mesh net at each station sampled in the southern Brazilian Bight during 1975 and 1982 and the volume of plankton interpolated, obtained at the same stations during the same years. Small black dots represent the negative stations.

No correlations between egg abundance sampled with the $0.333 \mathrm{~mm}$ and the $0.505 \mathrm{~mm}$ mesh nets were observed for E. anchoita and type D eggs, making it impossible to establish a correction factor (Figure 4).

\section{DISCUSSION}

A bongo net towed at a low speed had been considered to be the best sampling gear for ichthyoplankton surveys (SMITH; RICHARDSON, 1977), but bongo nets do not prevent some problems inherent to the process of sampling plankton, such as clogging, avoidance and extrusion. Clogging is responsible for the reduced ratio between porosity and the filtering area due to the accumulation of particles in the mesh openings (VANNUCCI, 1968). The clogging rate is affected by: composition and density of suspended materials in the water, mesh size, the ratio of the filtering to the mouth area, and the form of the net (SMITH et al., 1968). Avoidance is size-dependent: 
Table 3. Number of eggs measured $(\mathrm{N})$, size range, mean and standard deviations of the major and minor axes for each Engraulidae egg type sampled in southern Brazilian Bight during 1975 and 1982 using a bongo net fitted with a 0.333 mm and $0.505 \mathrm{~mm}$ mesh net. $P$-values $(P)$ of Student's $t$-test.

\begin{tabular}{|c|c|c|c|c|c|c|c|c|c|c|c|c|}
\hline & \multicolumn{7}{|c|}{ Major Axis (mm) } & \multicolumn{5}{|c|}{ Minor Axis (mm) } \\
\hline & \multicolumn{2}{|c|}{$\mathbf{N}$} & \multicolumn{2}{|c|}{ Size Range } & \multicolumn{2}{|c|}{ Mean \pm SD } & \multirow[t]{2}{*}{$P$} & \multicolumn{2}{|c|}{ Size Range } & \multicolumn{2}{|c|}{ Mean \pm SD } & \multirow[t]{2}{*}{$P$} \\
\hline & 0.333 & 0.505 & 0.333 & 0.505 & 0.333 & 0.505 & & 0.333 & 0.505 & 0.333 & 0.505 & \\
\hline Type A & 117 & 274 & $1.17-1.61$ & $1.20-1.57$ & $1.39 \pm 0.07$ & $1.36 \pm 0.06$ & $<0.01$ & $0.62-0.82$ & $0.60-0.80$ & $0.72 \pm 0.05$ & $0.70 \pm 0.04$ & $<0.01$ \\
\hline Type B & 57 & 91 & $0.91-1.18$ & $0.97-1.17$ & $1.10 \pm 0.05$ & $1.06 \pm 0.04$ & $<0.01$ & $0.63-0.78$ & $0.62-0.73$ & $0.71 \pm 0.04$ & $0.67 \pm 0.02$ & $<0.01$ \\
\hline E. anchoita & 898 & 559 & $0.85-1.21$ & $0.83-1.23$ & $1.03 \pm 0.06$ & $1.01 \pm 0.07$ & $<0.01$ & $0.45-0.63$ & $0.42-0.62$ & $0.52 \pm 0.03$ & $0.52 \pm 0.03$ & 0.42 \\
\hline Type D & 194 & 155 & $0.76-0.99$ & $0.67-1.01$ & $0.89 \pm 0.05$ & $0.88 \pm 0.05$ & 0.08 & $0.45-0.71$ & $0.47-0.70$ & $0.56 \pm 0.05$ & $0.55 \pm 0.04$ & 0.32 \\
\hline
\end{tabular}
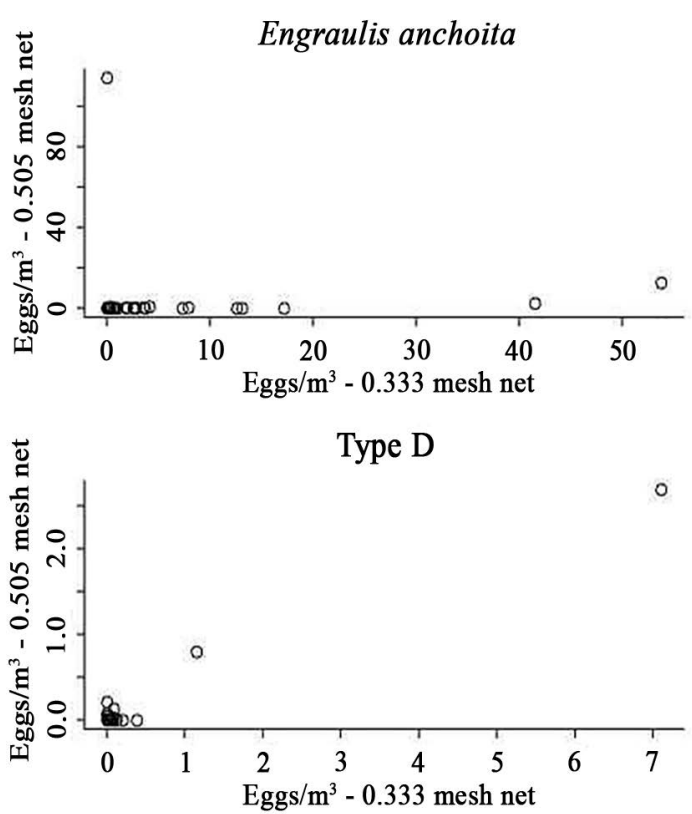

Figure 4. Plot of the abundance of eggs sampled with the $0.333 \mathrm{~mm}$ mesh net versus the abundance of eggs sampled with the $0.505 \mathrm{~mm}$ mesh net for Engraulis anchoita and type D eggs.

as larvae grow and develop, they improve their ability to detect net pressure and their swimming ability, evading plankton nets (JOHNSON; FOGARTY, 2013). Extrusion represents the loss of ichthyoplankton through the net meshes by the combined effects of hydraulic pressure, morphology and size of the fish larvae and eggs, net mesh size and stability (VANNUCCI, 1968). Increasing the towing speed may improve the catch efficiency of larger zooplankton, but results in greater loss of small individuals by extrusion. In general, smaller fish eggs and larvae are extremely vulnerable to changes in filtration pressure and extrusion (SMITH; RICHARDSON, 1977). Furthermore, ichthyoplankton patchiness makes sampling of these organisms even more difficult. Of all the problems cited, we can easily eliminate avoidance in this present study, as fish eggs cannot swim away from a net.
In a conical net, water flow is evenly distributed throughout its length and, if clogging occurs, it will be distributed evenly over the entire surface. In the combined cylindrical and cone designed net (as in the bongo net used) some of the water is naturally diverted by the cone model and is filtered through the cylinder (CURRIE, 1963). The porous cylindrical part, in front of the filtering cone, probably oscillates in response to eddies caused by the ring, and so cleans itself of accumulated organisms, reducing the rate of clogging (TRANTER; SMITH, 1968).

Fine-mesh nets, with comparable filtering areas, filter initially as well as larger mesh sizes do, but clog more rapidly. In the relatively clear water of Catalina Island, California, three different mesh size nets maintained high filtering efficiency for 18 minutes, after which the $0.101 \mathrm{~mm}$ mesh net clogged to $83 \%$ efficiency and after 30 minutes the $0.201 \mathrm{~mm}$ mesh net clogged to $84 \%$ efficiency. The $0.333 \mathrm{~mm}$ mesh net had about $85 \%$ filtration efficiency during one hour of towing (SMITH et al., 1968). SOMERTON and KOBAYASHI (1989) studying Hawaii anchovy eggs (Encrasicholina purpurea), observed that the catch of the plankton net of a $0.183 \mathrm{~mm}$ mesh size was significantly less than that of a $0.335 \mathrm{~mm}$ one, indicating that the smaller mesh net was likely clogged. HERNANDEZ et al. (2011) found no differences in total fish larvae and egg densities between $0.333 \mathrm{~mm}$ and 0.200 $\mathrm{mm}$ mesh bongo nets. Those authors observed that only two out of 22 pairs of samples clogged, mainly because of the low volume of water filtered during their $1-18 \mathrm{~m}$ oblique tows, of approximately $67 \mathrm{~m}^{3}$. In the present study, since we used conical- cylinder nets of 0.333 and 0.505 $\mathrm{mm}$ mesh, larger than those used in the studies discussed above, our tows did not last more than 15 minutes, and as the $0.505 \mathrm{~mm}$ mesh net did not sample more eggs at the stations with higher plankton abundance, where the 0.333 mm net would clog, we can also disregard the clogging effect. 
A number of studies have documented the effect of mesh size on the retention of larvae, with the general conclusion that larger mesh sizes efficiently collect the late ontogenetic stages but underestimate the initial larval stages due to extrusion (e.g. HOUDE; LOVDAL, 1984; LESLIE; TIMMINS, 1989). In contrast, smaller-mesh nets collect smaller size classes of larvae, but are prone to clogging - thus reducing their effectiveness in sampling larger size classes (SMITH et al., 1968; TRANTER; SMITH, 1968). In this regard, inappropriate mesh-size nets are one of the most important sources of sampling bias affecting organism size and development stage data (SMITH et al. 1968; COLTON et al. 1980). In our results, the eggs of each Engraulidae type exhibited low variations of the major and minor diameters and the $0.333 \mathrm{~mm}$ mesh net sampled type A and B eggs larger than the ones sampled in the 0.505 $\mathrm{mm}$ mesh net, the opposite of what was expected. For E. anchoita and type D eggs, which were more abundant in samples of the $0.333 \mathrm{~mm}$ mesh net, there were no size differences when the two nets were compared. Thus, the different mesh used had no egg size selectivity within each egg type, and our data presented no length-frequency bias.

Another reason why the quantitative difference for E. anchoita and type D eggs cannot be associated when comparing both nets with the egg size is that there were minor variations in axes varying from 0.45 to 0.71 $\mathrm{mm}$, the smaller dimension being smaller than the 0.505 $\mathrm{mm}$ mesh aperture and the mesh diagonal. In our study we used nets that had diagonals of approximately 0.45 and $0.71 \mathrm{~mm}$ for the 0.333 and $0.505 \mathrm{~mm}$ nets, respectively. SMITH et al. (1968) summarized the results of SAVILLE (1958) and concluded that the maximum cross-section diameter of an organism must be wider than the mesh diagonal to be fully retained. Some authors considered this "Diagonal rule" too conservative (e.g. LENARZ, 1972; SANCHEZ; CIECHOMSKI, 1984; SOMARAKIS et al., 1998). The engraulid eggs, excluding type $\mathrm{D}$, only had a major axis larger than the $0.71 \mathrm{~mm}$ diagonal and all the eggs of E. anchoita and type $\mathrm{D}$, and some eggs of types A and B had a minor axis smaller than $0.71 \mathrm{~mm}$. Since we cannot confirm whether ellipsoid eggs were retained due to their minor or major axes, we believe that the "Diagonal rule" was not applicable in this study.

The patchiness of planktonic fish eggs and larvae has been well described (e.g. MCGURK, 1986;
MATSUURA; HEWITT, 1995; BRADBURY et al., 2003; MAYNOU et al., 2006), even for some species of the Engraulidae (HEWITT, 1981). The role of patchiness as a component of the sampling bias was studied by WIEBE and HOLLAND (1968) and WIEBE $(1970 ; 1971)$. These studies emphasized the importance of the size analyses, distribution and density of zooplankton patches for the understanding of the sampling bias. The large values of the abundance amplitude in the present study indicate patchiness in the occurrence of the Engraulidae eggs, but no conclusion about the characteristics of these patches can be drawn from our data. Further studies on patch size and density and whether it is possible for one bongo net to pass through the patch and the other not, or the possibility for one net to pass through a denser part of the patch must be undertaken to confirm whether the differences in sampling Engraulidae eggs with different mesh nets are caused by patchiness. The patchiness effect could also explain why eggs of all types were sampled in the $0.505 \mathrm{~mm}$ mesh net but were absent in the $0.333 \mathrm{~mm}$ mesh net at some stations, and why at one station the $0.505 \mathrm{~mm}$ mesh net abundance of $E$. anchoita was much higher than the abundance sampled with the $0.333 \mathrm{~mm}$ mesh net, with a difference of 114 eggs $/ \mathrm{m}^{3}$. If the difference in mesh retention was the only factor involved, this would not happen.

As in our results, in MATSUURA and NAKATANI (1980) the $0.333 \mathrm{~mm}$ mesh net collected more E. anchoita eggs than the $0.505 \mathrm{~mm}$ mesh net in the Santos area of the southern Brazilian coast in November 1977. However, those authors only sampled five fixed stations and did not evaluate the abundance difference at each station, or if there was any mesh effect on the egg size. On the other hand, SANCHEZ and CIECHOMSKI (1984) analyzing E. anchoita eggs sampled on the Uruguayan and Argentinian coasts during the spring of 1981 did not observe any difference in the abundance obtained with the 0.333 and the $0.505 \mathrm{~mm}$ mesh nets. According to SANCHEZ and CIECHOMSKI (1984), the difference in the results is caused by the regional variation, as the minor axis of the E. anchoita eggs sampled on the Uruguayan and Argentinian coasts was larger than the ones sampled in the Santos area and also greater than those sampled in the present study. The dimension of the minor axis varied between 0.68 and $0.70 \mathrm{~mm}$ on the Uruguayan and Argentinian coasts (CIECHOMSKI, 1973); on 
the Brazilian southeast coast, the minor axis mean value observed by MATSUURA and NAKATANI (1980) was of $0.58 \mathrm{~mm}$ and, in the present study, of $0.52 \mathrm{~mm}$. It is known that the southeastern Brazilian Bight, excluding the Santa Marta Cape region, has one unit stock of E. anchoita and southern Brazil another (CARVALHO; CASTELLO, 2013). The southern Brazil stock is the same as that named bonaerense off Argentina and Uruguay (CARVALHO; CASTELLO, 2013).

The extent to which clogging, avoidance and extrusion of fish larvae and eggs is a problem depends upon the objective of the study. Ecological studies of ichthyoplankton communities, e.g. dominant species and species composition, will be subject to some bias as a result of these problems, but this bias may not be serious. However, studies of the distribution and abundance of newly-hatched larvae or the estimate of mortality rates from length frequencies will incorporate serious bias if clogging, avoidance and extrusion losses are overlooked (JOHNSON; MORSE, 1994). As there were no differences in the abundance of Engraulidae eggs of types A and B in the two mesh sizes tested, the results obtained with each net were comparable. On the other hand, our results showed that the $0.333 \mathrm{~mm}$ mesh net tends to sample more E. anchoita and type $\mathrm{D}$ eggs than that of $0.505 \mathrm{~mm}$, but as no correlation was observed between these eggs captured in the two nets, we could not calculate any correlation factor to facilitate the comparisons. As discussed above, we can ignore avoidance, clogging and egg-size mesh-selectivity effects as they do not affect these results. Thus, the difference between the eggs captured at each station seems to occur randomly due to egg patchiness or to other, unanalyzed, factors.

In conclusion, the abundance of Engraulidae eggs sampled with a bongo net of $0.333 \mathrm{~mm}$ and $0.505 \mathrm{~mm}$ mesh sizes in the southeastern Brazilian Bight can be compared if they are of types A or B, but if they are Engraulis anchoita or of type D, some caution is recommended when comparing these results.

\section{ACKNOWLEDGEMENTS}

The authors thank those responsible for the Biological Collection "Prof. E. F. Nonato" (Oceanographic Institute, University of São Paulo) for the egg samples. The first author is thankful for the scholarships given by Fundação de Amparo à Pesquisa do Estado de São Paulo (FAPESP). Comments and suggestions from Antônio Olinto Ávila da Silva, June Ferraz Dias, Rubens Mendes Lopes and two anonymous reviewers, improved the quality of this manuscript, for which the authors are grateful.

\section{REFERENCES}

AUTH, T. B.; BRODEUR, R. D.; SOULEN, H. L.; CIANNELLI, L.; PETERSON W.T. The response of fish larvae to decadal changes in environmental forcing factors off the Oregon coast. Fish. Oceanogr., v. 20, n. 4, p. 314-328, 2011.

BARKLEY, R. A. Selectivity of towed-net samplers. Fish. Bull. U. S., v. 70, n. 3, p. 799-820, 1972.

BRADBURY, I. R.; SNELGROVE, P.V. R.; PEPIN, P. Passive and active behavioural contributions to patchiness and spatial pattern during the early life history of marine fishes. Mar. Ecol. Prog. Ser., v. 257, p. 233-245, 2003.

BRODEUR, R. D.; FROST, B.W.; HARE, S. R.; FRANCIS, R. C.; INGRAHAM, W.J. Interannual variations in zooplankton biomass in the gulf of Alaska, and covariation with California current zooplankton biomass. CalCOFl Rep., v. 37, p. 80-99, 1996.

CASTELLO, J.P. Síntese sobre a anchoíta (Engraulis anchoita) no sul do Brasil. In: HAIMOVICI, M. (Ed.). A prospecção pesqueira e abundância de estoques marinhos no Brasil nas décadas de 1960 a 1990: levantamento de dados e avaliação crítica. Brasília: MMA/SMCQ, 2007. p. 197-218.

CARVALHO, F.M.; CASTELLO, J.P. Argentine anchovy (Engraulis anchoita) stock identification and incipient exploitation in southern Brazil. Lat. Am. J. Aquat. Res., v. 41, n. 5, p. 820-827, 2013

CHUTE, A.S.; TURNER, J.T. Plankton studies in Buzzards Bay, Massachusetts, USA. V. Ichthyoplankton, 1987 to 1993. Mar. Ecol. Prog. Ser., v. 224, p. 45-54, 2001.

CIECHOMSKI, J.D. Observaciones sobre la reproduccion desarollo embrionario y larval de la Anchoita Argentina (Engraulis anchoita). Bol. Inst. Biol. Mar., v. 9, p. 1-29, 1965.

CIECHOMSKI, J.D. The size of the eggs of the Argentine anchovy, Engraulis anchoita (Hubbs \& Marini) in relation to the season of the year and to the area of spawning. J. Fish Biol., v. 5, p. 393-398, 1973.

COLTON JR., J.B.; GREEN, J.R.; BYRON, R.R.; FRISELLA, J.L. Bongo net retention rates as affected by towing speed and mesh size. Can. J. Fish. Aquat. Sci., v. 37, n. 4, p. 606-623, 1980.

CURRIE, R.I. The Indian Ocean Standard Net. Deep. Sea Res., v. 10, p. $27-32,1963$.

FAO. The State of World Fisheries and Aquaculture 2012. Food and Agriculture Organization of the United Nations Rome, 2012. 209 p.

GUILLE, A. Benthic Bionomy of continental shelf of french catalane coast. II. Benthic communities of the macrofauna. Vie Millieu, v. 21, n. 8, p. 149-280, 1970.

FAVERO, J. M.; KATSURAGAWA, M.; ZANI-TEIXEIRA, M. L.; TURNER, J. T. Using new tools to identify eggs of Engraulis anchoita (Clupeiformes, Engraulidae). J. Fish. Biol., v. 86, n. 2, p. 822-826, 2014. 
HERNANDEZ JR., F. J.; CARASSOUA, L.; MUFFELMANA, S.; POWERS, S.P.; GRAHAMA, W.M. Comparison of two plankton net mesh sizes for ichthyoplankton collection in the northern Gulf of Mexico. Fish Res., v. 108, n. 2-3, p. 327335, 2011

HEWITT, R. The value of pattern in the distribution of young fish. Rapp. P-V. Réun. Cons. Perm. Int. Explor. Mer, v. 178, p. 229-236, 1981.

HOUDE, E. D.; LOVDAL, J. A. Seasonality of Occurrence, Foods and Food Preferences of Ichthyoplankton in Biscayne Bay, Florida. Estuar. Coast. Shelf. Sci., v. 18, n, 4, p. 403419, 1984

JOHNSON, D. L.; FOGARTY, M. J. Intercalibration of MOCNESS and Bongo nets: Assessing relative efficiency for ichthyoplankton. Prog. Oceanogr., v. 108, p. 43-71, 2013.

JOHNSON, D. L.; MORSE, W.W. Net Extrusion of Larval Fish: Correction Factors for $0.333 \mathrm{~mm}$ Versus $0.505 \mathrm{~mm}$ Mesh Bongo Nets. NAFO. Sci. Coun. Studies., v. 20, p. 85-92, 1994.

LENARZ, W. H. Mesh retention of larvae of Sardinops caerulea and Engraulis mordax by plankton nets. Fish. Bull., v. 70, n. 3, p. 839-848, 1972.

LESLIE, J. K.; TIMMINS, C. A. Double nets for mesh aperture selection and sampling in ichthyoplankton studies. Fish Res., v. 7, n. 3, p. 225-232, 1989 .

MADUREIRA, L. S. P.; CASTELLO, J. P.; PRENTICE-HERNÁNDEZ, C.; QUEIROZ, M. I.; ESPÍRITO SANTO, M. L.; RUIZ, W. A.; RAGGI ABDALLAH, P.; HANSEN, J.; BERTOLOTTI, M. I.; MANCA, E.; YEANNES, M. I.; AVDALOV, N.; AMORÍN, S. F. Current and potential alternative food uses of the Argentine anchoita (Engraulis anchoita) in Argentina, Uruguay and Brazil. In: HASAN, M. R.; HALWART, M. (Eds.). Fish as feed inputs for aquaculture: practices, sustainability and implications. Fisheries and Aquaculture Technical Paper, FAO, Rome, 2009. p. 269-287.

MAKABE, R.; TANIMURA, A.; FUKUCHI, M. Comparison of mesh size effects on mesozooplankton collection efficiency in the Southern Ocean. J. Plankton. Res., v. 34, n. 5, p. 432436, 2012.

MATSUURA, Y.; HEWITT, R. Changes in the spatial patchiness of Pacific mackerel, Scomberjaponicus, larvae with increasing age and size. Fish. Bull., v. 93, n. 1, p. 172-178, 1995.

MATSUURA, T.; NAKATANI, K. Variability in quantity of zooplankton, fish eggs and larvae associated with two different mesh sizes in bongo nets. Atlântica, v. 4, p. 43-52, 1980.

MAYNOU, F.; OLIVAR, M. P.; EMELIANOV, M. Patchiness of eggs, larvae and juveniles of European hake Merluccius merluccius from the NW Mediterranean. Fish Oceanogr., v. 15, n. 5, p. 390-401, 2006.

MCGURK, M. D. Natural mortality of marine pelagic fish eggs and larvae: role of spatial patchiness. Mar. Ecol. Prog. Ser., v. 34, p. 227-242, 1986.

MILLER, M. J.; STEPPUTTIS, D.; BONHOMMEAU, S.; CASTONGUAY, M.; SCHABER, M.; VOBACH, M.; WYSUJACK, K.; HANEL, R. Comparisons of catches of large leptocephali using an IKMT and a large pelagic trawl in the Sargasso Sea. Mar. Biodiv., v. 43, n. 4, p. 493-501, 2013.

MULLIN, M. M. Interannual and interdecadal variation in $\mathrm{Ca}-$ lifornia Current zooplankton: Calanus in the late1950s and early 1990s. Glob. Change. Biol., v. 4, n. 1, p. 115-119, 1998.
NAGASAWA, K. Long-term variations in abundance of Pacific herring (Clupea pallasi) in Hokkaido and Sakhalin related to changes in environmental conditions. Prog. Oceanogr., v. 49, n. 1, p. 551-564, 2001.

PEPIN, P.; SHEARS, T. H. Variability and capture efficiency of bongo and Tucker trawl samplers in the collection of ichthyoplankton and other macrozooplankton. Can. J. Fish. Aquat. Sci., v. 54, n. 4, p. 765-773, 1997.

PHONLOR, G. Morfologia e Biologia dos ovos de Engraulidae do sul do Brasil (Teleostei, Clupeiformes). Rev. Bras. Biol., v. 44, n. 4, p. 467-487, 1985.

R CORE TEAM. 2012. R: A language and environment for statistical computing. Vienna: R Foundation for Statistical Computing, 2012. Available at: http://www.R-project.org/. Accessed on: 19 Jan. 2014.

REBSTOCK, G. A. An analysis of a zooplankton sampling-gear change in the CalCOFI long-term monitoring program, with implications for copepod population abundance trends. Prog. Oceanogr., v. 53, n. 2-4, p. 215-230, 2002.

SÁNCHEZ, R. P.; CIECHONSKI. J. D. Estimación de la biomassa de adultos desovantes de la anchoíta (Engraulis anchoita) en el área costera bonaerense durante la primavera de 1981 y análisis comparativo de los recuentos de ictioplancton con redes de diferentes mallas. Rev. invest. Des. Pesq., v. 4, p. 49-61, 1984.

SAVILLE, A. Mesh selection in plankton nets. J. Cons. Int. Explor. Mer., v. 23, p. 192-201, 1958.

SKJOLDAL, H. R.; WIEBE, P. H.; POSTEL, L.; KNUTSEN, T.; KAARTVEDT S.; SAMEOTO, D. D. Intercomparison of zooplankton (net) sampling systems: Results from the ICES/ GLOBEC sea-going workshop. Prog. Oceanogr., v.108, p. $1-42,2013$.

SMITH, P. E.; RICHARDSON, S. L. Standard techniques for pelagic fish egg and larva surveys. FAO. Fish. Tech. Pap., v. 175, p. 1-100, 1977.

SMITH, P. E.; COUNTS, R. C.; CLUTTER, R. I. Changes in filtering efficiency of plankton nets due to clogging under tow. J. Cons. Int. Explor. Mer, v. 32, n. 2, p. 232-248, 1968.

SOMARAKIS, S.; CATALANO, B.; TSIMENIDES, N. Catchability and retention of larval European anchovy, Engraulis encrasicolus, with bongo nets. Fish. Bull., v. 96, n. 4, p. 917925, 1998.

SOMERTON, D. A.; KOBAYASHI, D. R. A method for correcting catches of fish larvae for the size selection of plankton nets. Fish. Bull. S. U., v. 87, n. 3, p. 447-455, 1989.

STRATOUDAKIS, Y.; BERNAL, M.; BORCHERS, D. L.; BORGES, M. F. Changes in the distribution of sardine eggs and larvae off Portugal, 1985-2000. Fish Oceanogr., v. 12, n. 1, p. 49-60, 2003.

TRANTER, D. J.; SMITH, P. E. Filtration Performace. In: TRANTER, D. J.; FRASER, J. H. (Eds.). Zooplankton sampling, UNESCO monographs on oceanographic methodology. Paris: UNESCO, 1968. p. 27-56.

TSENG, L. C.; DAHMS, H.U.; HUNG, J. J.; CHEN, Q. C.; HWANG, J. S. Can different mesh sizes affect the results of copepod community studies? J. Exp. Mar. Biol. Ecol.,v. 398, n. 1, p. $47-55,2011$

TURNER, J.T.; BORKMAN, D.G.; LIBBY, P.S. Zooplankton trends in Massachusetts Bay, USA: 1998-2008. J. Plankton Res., v. 33, n. 7, p. 1066-1080, 2011. 
VANNUCCI, M. Loss of organisms through the meshes. In: TRANTER, D.J.; FRASER, J.H. (Eds.). Zooplankton sampling, UNESCO monographs on oceanographic methodology. Paris: UNESCO, 1968. p. 77-86.

WIEBE, P. H. Small-scale spatial distribution in oceanic zooplankton. Limnol. Oceanogr., v. 15, n. 2, p. 205-217, 1970.

WIEBE, P. H. A computer model study of zooplankton patchiness and its effects on sampling error. Limnol. Oceanogr., v. 16, n. 1, p. 29-38, 1971.
WIEBE, P. H.; Benfield, M. C. From the Hensen net toward four-dimensional biological oceanography. Prog. Oceanogr., v. 56, n. 1, p. 7-136, 2003.

WIEBE, P. H.; Holland, W. R. Plankton patchiness: effects on repeated net tows. Limnol. Oceanogr., v. 13, n. 2, p. 315-321, 1968.

ZAR, J. H. Biostatistical Analysis. Upper Saddle River: Prentice Hall, 1999. 662 p. 